\title{
Toxicity of Cry2 proteins from Bacillus thuringiensis subsp. thuringiensis strain TO1-328 against Aedes aegypti (Diptera: Culicidae)
}

\author{
Toxicidade das proteínas Cry2 do Bacillus thuringiensis subsp. \\ thuringiensis T01-328 contra Aedes aegypti (Diptera: Culicidae)
}

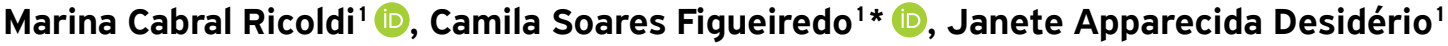

| | | | | | | | | | | | | | | | | | | | | | | | | | | | | | | | | | | | | | | | | | | | | | | | | | | | | | | | | | | | | | | | | | | | | | | | | | | | | | | | | | | | | | | | | | | | | | | | | | | | | | | | | | | | | | | | | | | | | | | | | | | | | | | | | | | | | | | | | | | | | | | | | | | | | | | | | | | | | | | | | | | | | | | | | | | | | | | | | | | | | | | | | | | | | | | | | | | | | |

\begin{abstract}
Bacillus thuringiensis subsp. israelensis has been used to control the Aedes aegypti (Diptera: Culicidae) mosquito larvae, the vector of virus diseases such as dengue, Chikungunya and Zika fever, which have become a major public health problem in Brazil and other tropical countries since the climate favors the proliferation and development of the transmitting vector. Because B. thuringiensis has shown potential for controlling insects of the Diptera order, this work aimed at testing the Bacillus thuringiensis subsp. thuringiensis strain T01-328 and its proteins Cry2Aa and Cry2Ab for control A. aegypti and at comparing the results to the $B$. thuringiensis subsp. israelensis specific dipteran strain. To this end, bioassays using spore-crystal of both strains, and Cry2Aa and Cry $2 \mathrm{Ab}$ proteins from the heterologous expression in Escherichia coli, were performed against $A$. aegypti larvae. The results showed that the $B$. thuringiensis thuringiensis T01-328 has insecticidal activity against the larvae, but it is less toxic than $B$. thuringiensis subsp. israelensis. Cry2Aa and Cry2Ab proteins expressed heterologously were effective for controlling $A$. aegypti larvae. Therefore, the results indicate that the Cry $2 \mathrm{Aa}$ and Cry $2 \mathrm{Ab}$ proteins of the $B$. thuringiensis thuringiensis T01-328 can be used as an alternative to assist in the control of $A$. aegypti.
\end{abstract}

KEYWORDS: Cry proteins; biological control; dengue; Zika; mosquito.
RESUMO: Bacillus thuringiensis subsp. israelensis vem sendo empregada no controle do díptero Aedes aegypti, vetor do vírus causador de doenças como dengue, febre Chikungunya e Zika, que se tornou um dos grandes problemas de saúde pública no Brasil e em outros países de clima tropical, que favorece a proliferação e o desenvolvimento do transmissor. Em virtude do potencial de $B$. thuringiensis no controle de dípteros, a proposta deste trabalho foi testar as proteínas Cry2Aa e Cry2Ab da linhagem de Bacillus thuringiensis subsp. thuringiensis T01-328 no controle de A. aegypti, em comparação à linhagem díptero específica $B$. thuringiensis subsp. israelensis. Para tanto, foram realizados bioensaios com larvas de A. aegypti com o esporo-cristal de ambas as linhagens, bem como com as proteínas Cry2Aa e Cry2Ab com expressão heteróloga em Escherichia coli. A linhagem $B$. thuringiensis thuringiensis T01-328 apresentou atividade inseticida contra as larvas, porém foi menos tóxica que a B. thuringiensis subsp. israelensis. As proteínas Cry2Aa e Cry2Ab expressas de forma heteróloga foram eficazes no controle de $A$. aegypti. Os resultados obtidos sugerem as proteínas Cry $2 \mathrm{Aa}$ e Cry2Ab da linhagem $B$. thuringiensis thuringiensis T01-328 como alternativas para contribuir no controle do $A$. aegypti.

PALAVRAS-CHAVE: proteínas Cry; controle biológico; dengue; Zika; mosquito. 


\section{INTRODUCTION}

Dengue is one of the major public health problems in tropical countries, and its incidence has increased dramatically around the world in recent decades. During the 2017 Epidemiological Week, 251,711 probable cases of dengue were registered in the country according to the Health Department (BRASIL, 2018), although the actual numbers of dengue cases are underestimated and in many cases incorrectly classified. It is estimated that 500 thousand people with severe dengue require hospitalization each year, a large proportion of children and about $2 \%$ of those affected die (WHO, 2017).

In 2014 and 2015, health officials also identified cases of Chikungunya and Zika fevers in Brazil, both caused by viruses that are carried and transmitted by Aedes aegypti mosquitoes (BRASIL, 2014). Furthermore, Zika fever, caused by the Zika virus (ZIKV), can be transmitted via mosquito bite, as well as sexually from human to human and vertically, from mother to fetus (D'ORTENZIO et al., 2016; MANSUY et al., 2016). Maternal transmission to the fetus presents a serious risk of causing fetal congenital anomalies (SCHULER-FACCINI et al., 2016).

These tropical diseases are mainly controlled by combating its transmitting vector. One of the methods used is the chemical control, which consists of using chemical insecticides to kill the mosquitoes. However, the rapid increase of mosquito resistance to various chemical insecticides containing one or few active ingredients that promote selection insects resistant and the growing public concern about environmental pollution have resulted in the development of alternatives for controlling the mosquitoes, such as using the biological agent Bacillus thuringiensis subsp. israelensis (Bti). In addition, A. aegypti ranks the first in the list of Diptera species with the highest number of resistance cases worldwide (ARTHROPOD PESTICIDE RESISTANCE DATABASE, 2018).

Bacillus thuringiensis subsp. israelensis is highly relevant in the fight against the dengue vector, since it acts as an efficient biolarvicide integrated in the $A$. aegypti Control Program (PCA), conducted in several municipalities affected by the disease (BRAGA et al., 2004). In Rio de Janeiro, Ceará, and Rio Grande do Norte, it was recommended to replace the Temephos (organophosphorus) insecticide with biolarvicides based on B. thuringiensis subsp. israelensis, considered one of the most effective biological control agents against culicids (BRASIL, 2000). The larvicidal action of B. thuringiensis subsp. israelensis is achieved by the expression of the Cry4Aa, Cry4Ba, Cry11Aa, Cyt1Aa, Cry10Aa and Cyt2Ba proteins, whose synergistic action reduces the probability of resistance selection. Despite the lack of reports on the emergence of $A$. aegypti resistance to bioinsecticides based on this subspecies in the field, it is important to search proteins with alternative action mode that can be used for controlling the mosquito (BEN-DOV, 2014). Furthermore, it is also essential to study other $B$. thuringiensis subspecies pathogenic to $A$. aegypti that could represent a promising source of control agents for eventual use in the future.

Thus, the present work aimed at investigating the bioinsecticidal potential of the $B$. thuringiensis thuringiensis strain T01-328 to control the $A$. aegypti vector. This strain genome is sequenced in the GenBank with the ARXZ020000000 accession number, so that the promising genes with bioinsecticidal activity against dipterans were identified (VARANI et al., 2013).

\section{MATERIALS AND METHODS}

\section{Dipterans}

The $A$. aegypti eggs were kindly provided by the Malaria and Dengue Laboratory of the National Research Institute of Amazonas, in Manaus, Amazonas, Brazil. After egg hatching, the larvae were maintained in water and kept in airconditioned (Bio-Oxygen Demand) B.O.D. incubator at 25 $\pm 2{ }^{\circ} \mathrm{C}, 70 \% \pm 10 \%$ relative humidity, and $14 \mathrm{~h}$ light: $10 \mathrm{~h}$ dark photoperiod. The larvae were fed with three-pellet feed for reptiles (Reptolife).

\section{Bacterial spore-crystal bioassays with Bacillus thuringiensis}

Bacillus thuringiensis subsp. thuringiensis strain T01-328 and Bacillus thuringiensis subsp. israelensis T14001 (positive dipteran control) were cultured in solid nutrient agar medium $(3.0 \mathrm{~g} / \mathrm{L}$ meat extract, $5.0 \mathrm{~g} / \mathrm{L}$ gelatin peptone, $15.0 \mathrm{~g} / \mathrm{L}$ agar and $\mathrm{pH}$ 6.8) (GORDON et al., 1982) and incubated at $30^{\circ} \mathrm{C}$ for 5 days, as to allow complete sporulation and crystal release. After this period, all bacterial contents were retrieved from the culture using a platinum loop and transferred into tubes containing $10 \mathrm{~mL}$ of sterile distilled water and $0.05 \%$ Tween (adhesive spreader). The obtained spore-crystal suspension was homogenized by vortexing, and the suspended material was diluted, so that the spores were counted using the Neubauer Chamber placed on the optical microscope stage (ALVES; MORAES, 1998). The strains were tested at five different concentrations $\left(3.0 \times 10^{9}, 1.5 \times 10^{9}, 0.75 \times 10^{9}, 0.38 \times 10^{9}\right.$ and $0.19 \times 10^{9}$ spore-crystal $/ \mathrm{mL}$ ). Twenty $3^{\text {rd }}$-instar larvae were placed in plastic cups containing $200 \mathrm{~mL}$ of deionized water (negative control) and water plus the spore-crystal suspension of the studied strains (five treatments) with three replicates per treatment. The bioassays were kept in B.O.D. incubator at $25 \pm 2{ }^{\circ} \mathrm{C}$ and $12 \mathrm{~h}$ light: $12 \mathrm{~h}$ dark photoperiod. In data analysis, mortalities corrected according to Abbott's formula, from different replicates, were grouped for analysis (WHO, 2005). The $\mathrm{LC}_{50}$ was determined using the probit analysis of the POLO-PC statistic software (LeOra Software, Berkeley, California, United States). 


\section{Obtaining the Cry2Aa and Cry2Ab proteins}

Escherichia coli BL21 (DE3) clones containing the cry $2 A a$ and $c r y 2 A b$ gene of the B. thuringiensis thuringiensis strain T01-328 cloned in the pET-Sumo vector (Invitrogen, Carlsbad, California, United States) were cultured in Luria Bertani medium (LB) with kanamycin $(50 \mu \mathrm{g} / \mathrm{mL})$. An isolated colony was transferred to liquid LB medium supplemented with kanamycin $(50 \mu \mathrm{g} / \mathrm{mL})$ and multiplied under constant stirring at $250 \mathrm{rpm}$ and $37^{\circ} \mathrm{C}$ for $16 \mathrm{~h}$ (Eppendorf / New Brunswick Scientific Innova 4340 Illuminated Refrigerated Incubator Shaker). When the cultures prepared from the pre-inoculum reached optical density $(\mathrm{O} . \mathrm{D})_{600} 0.6$, they were induced to express the proteins by adding $0.5 \mathrm{mM}$ isopropyl $\beta$-D-1-thiogalactopyranoside (IPTG). The cultures were maintained at $200 \mathrm{rpm}$ and $22^{\circ} \mathrm{C}$ for $16 \mathrm{~h}$ (Eppendorf / New Brunswick Scientific Innova 4340 Illuminated Refrigerated Incubator Shaker). Subsequently, they were centrifuged at 17,400 $\mathrm{g}$ for $20 \mathrm{~min}$, and the cells were resuspended in extraction buffer $(50 \mathrm{mM}$ potassium phosphate, $\mathrm{pH} 7.8,400 \mathrm{mM} \mathrm{NaCl}, 100 \mathrm{mM} \mathrm{KCl}, 10 \%$ glycerol, $0.5 \%$ Triton X-100, $10 \mathrm{mM}$ imidazole) plus $3 \mathrm{mg} / \mathrm{mL}$ lysozyme and $0.01 \mathrm{mg} / \mathrm{mL}$ deoxyribonuclease (DNAse), and kept at $200 \mathrm{rpm}$ and $37^{\circ} \mathrm{C}$, for $30 \mathrm{~min}$ (Eppendorf / New Brunswick Scientific Innova 4340 Illuminated Refrigerated Incubator Shaker). The samples were sonicated at $60 \mathrm{~W}$ for $60 \mathrm{~s}$, twice, with a 10-second interval. Finally, the lysates were centrifuged at $17,400 \mathrm{~g}$ and $4{ }^{\circ} \mathrm{C}$ for $30 \mathrm{~min}$, and the supernatants were stored at $-20^{\circ} \mathrm{C}$ until further use. The same culture and extraction procedures were performed starting from E. coli BL21 (DE3) colony without the expression vector.

The protein expression was verified on $12 \%$ sodium dodecyl sulfate polyacrylamide electrophoresis gel (SDS-PAGE), according to LAEMMLI (1970). The concentration of the Cry2Aa and Cry $2 \mathrm{Ab}$ proteins in each extract was obtained by SDS-PAGE densitometry using serum bovine albumin as a standard in the ImageQuant TL 8.1 software (GE Healthcare Bio-Sciences, AB, Uppsala, Sweden).

\section{Bioassays with the Cry2Aa and Cry2Ab proteins against Aedes aegypti}

The Cry2Aa and Cry2Ab proteins and the Cry $2 \mathrm{Aa}+\mathrm{Cry} 2 \mathrm{Ab}$ protein mixture were distributed in cups at the concentrations of $10,20,40,50$ and $60 \mu \mathrm{g} / \mathrm{mL}$. Two controls were used: deionized water and E. coli lysate from a culture without induction of heterologous expression. The treatments were performed in triplicate with 20 larvae per replicate. Mortality rate was evaluated after the larvae were exposed to the treatment for 24 hours, and only completely inert larvae were counted as dead. The bioassays were kept in B.O.D. incubator at $25 \pm 2^{\circ} \mathrm{C}$, and $12 \mathrm{~h}$ light: $12 \mathrm{~h}$ dark photoperiod. The $\mathrm{LC}_{50}$ and $\mathrm{LC}_{90}$ were estimated by the probit analysis of the POLO-PC software (LeOra Software, Berkeley, California, United States). The interaction between the proteins was analyzed at 1:1 protein ratio according to TABASHNIK (1992). The synergism factor (SF) was given by the expected and observed LC ratio.

\section{RESULTS}

\section{Spore/crystal bioassays with Bacillus thuringiensis subsp. thuringiensis strain T01-328 and $B$. thuringiensis israelensis}

Bioassays with the spore/crystal mixture were performed to evaluate the insecticidal activity of $B$. thuringiensis thuringiensis strain T01-328 against $A$. aegypti larvae (Table 1). The $\mathrm{LC}_{50}$ $9.1 \times 10^{8}$ spore-crystal $/ \mathrm{mL}$ obtained in the trials confirmed larva susceptibility to $B$. thuringiensis thuringiensis. However, $B$. thuringiensis thuringiensis strain T01-328 was less effective for controlling Diptera B. thuringiensis israelensis compared to the reference $B$. thuringiensis israelensis subspecies that caused $100 \%$ mortality at all concentrations indicating a $\mathrm{LC}_{50}$ less than $0.1875 \times 10^{9}$.

\section{Bioassay with Cry2Aa and Cry2Ab proteins}

The Cry2Aa and Cry2Ab heterologous expression was confirmed by visualizing the approximately $70 \mathrm{kDa}$ bands for both in the SDS-PAGE (Fig. 1).

Bioassays with Cry2Aa and Cry $2 \mathrm{Ab}$ proteins against A. aegypti larvae indicated that these proteins might be a promising alternative for mosquito control (Table 2). The equivalent

Table 1. Susceptibility of Aedes aegypti larvae to spore/crystal protein from Bacillus thuringiensis strains.

\begin{tabular}{|c|c|c|c|}
\hline Treatment & LC $_{50}$ (spore-crystal/mL) (CI Min. - Max.) ${ }^{a}$ & Chi-square & $b \pm(S E)^{b}$ \\
\hline \multirow{2}{*}{$\begin{array}{l}\text { B. thuringiensis thuringiensis } \\
\text { strain TO } 1-328\end{array}$} & $9.1 \times 10^{8}$ & \multirow{2}{*}{0.7} & \multirow{2}{*}{$1.8 \pm 0.5$} \\
\hline & $\left(4.2 \times 10^{8}-1.2 \times 10^{9}\right)$ & & \\
\hline B. thuringiensis subsp. israelensis & $<0.1875 \times 10^{9}$ & $N^{c}$ & ND \\
\hline
\end{tabular}


toxicity of the Cry2Aa and Cry $2 \mathrm{Ab}$ proteins used to control $A$. aegypti larvae is verified by the overlapping confidence interval of the obtained results. The Cry2Aa + Cry2Ab toxin mixture was slightly less toxic than expected, as the expected $\mathrm{LC}_{50}$ was below the limit of the observed $\mathrm{LC}_{50}$ confidence interval, thus suggesting an antagonistic tendency among proteins. However, the expected $\mathrm{LC}_{90}$ is within the observed $\mathrm{LC}_{90}$ confidence interval for $A$. aegypti larvae. The antagonism observed between the Cry2Aa and Cry2Ab proteins was weak at $\mathrm{LC}_{50}$ and disappeared at $\mathrm{LC}_{90}$.

\section{DISCUSSION}

Creating and maintaining $B$. thuringiensis collections is important for the characterization of new $\delta$-endotoxins that are effective against several insect orders.

The studied B. thuringiensis thuringiensis strain T01-328 has genes with insecticidal activity against Lepidoptera and

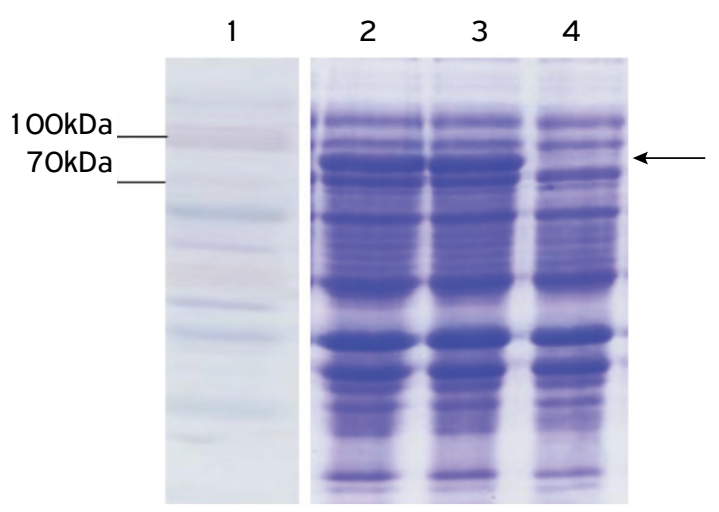

Figure 1. Sodium dodecyl sulfate polyacrylamide electrophoresis gel (SDS-PAGE) $12 \%$ of the heterologous expression of the Cry2A proteins in the channels: (1) Molecular Mass Marker (kDa) "Spectra ${ }^{\mathrm{TM}}$ Multicolor Broad Range ProteinLadder" (Fermentas); (2) Cry2Aa protein; (3) Cry2Ab protein
Coleoptera, which is important for agriculture, and showed toxic activity against Dipteran. The Cry2Aa and Cry2Ab proteins responsible for this activity exhibit $87 \%$ structural conservation between themselves (CRICKMORE, 2016).

Likewise, ARMENGOL et al. (2006) tested positive isolates carrying the $c r y 2, c r y 4$ and $c r y 11$ genes against Culex quinquefasciatus mosquitoes and reported higher efficiencies for $B$. thuringiensis subsp. israelensis positive control than the isolates carrying the $c r y 2$ only and $c r y 2 / c r y 11$ genes.

In another study, COSTA et al. (2010) performed bioassays to compare the $\mathrm{LC}_{50}$ of isolates selected for the $c r y 4 A a$, cry $4 B a$, cry $11 A a, c r y 11 B a, c y t 1 A a, c y t 1 A b, c y t 2 A a$ and $c h i$ genes and $B$. thuringiensis subsp. israelensis. After $24 \mathrm{~h}$, these authors reported that the treatment containing $1.5 \times 10^{7}$ spores-crys$\mathrm{tal} / \mathrm{mL}$ of B. thuringiensis subsp. israelensis caused $100 \%$ larval mortality, whereas the mortality rate of the other isolates ranged from 0 to $100 \%$ due to the presence of genes. In addition, isolates carrying the $c r y 4 B a$ and chi genes had mortality rates varying from 0 to $56 \%$, while the isolates carrying the $c r y 4 A a, c r y 4 A b$ and $c r y 11$ genes and one or more of the cyt $1 A b, c y t 2 A a$ and chi genes resulted in $100 \%$ mortality rate.

Similar to this work, this difference can be explained by the number of genes acting on these isolates since $B$. thuringiensis thuringiensis strain T01-328 has only two insecticidal genes, $c r y 2 A a$ and $c r y 2 A b$, in its genome, whereas $B$. thuringiensis subsp. israelensis strain carries eight genes, cry $4 A a$, cry $4 B a, c r y 11 A a$, cry11Ba, cyt1Aa, cyt1Ab, cyt2Aa, and chi. The proteins present in the B. thuringiensis subsp. israelensis (Cry4Ba, Cry11A, and Cyt) have synergistic effect, increasing subspecies efficiency on vector control (FERNÁNDEZ-LUNA et al., 2010). The synergistic action of these toxins reduces the likelihood of developing resistance against them (BECKER, 2000; REGIS et al., 2001).

Bacillus thuringiensis subsp. israelensis results in this study are similar to the mortality of $100 \%$ for $A$. aegypti larvae reported by LEE et al. (2005) and ESPINDOLA et al. (2008). LIMA et al. (2005) used the Bacillus thuringiensis subsp. israelensis to control the $3^{\text {rd }}$ instar larvae in containers made of different materials, under natural conditions in Rio de Janeiro,

Table 2. Susceptibility of Aedes aegypti larvae to Cry2Aa and Cry2Ab proteins from Bacillus thuringiensis subsp. thuringiensis strain TO1-328.

\begin{tabular}{|c|c|c|c|c|c|c|c|c|}
\hline Proteins & $\begin{array}{l}\mathrm{LC}_{50}(\mu \mathrm{g} \\
\text { (Cl Min. - }\end{array}$ & $\begin{array}{l}\text { nL) } \\
\text { ax.) }\end{array}$ & SF & $\begin{array}{l}\mathrm{LC}_{90}(\mu \\
\text { (Cl Min. }\end{array}$ & $\begin{array}{l}\text { nl) } \\
\text { ax.) }\end{array}$ & SF & $b \pm(S E)^{b}$ & $\chi^{2}$ \\
\hline \multirow{3}{*}{ Cry2Aa } & Observed & Expected & & Observed & Expected & & \multirow{2}{*}{$3.2 \pm 0.849$} & \multirow{2}{*}{1.8} \\
\hline & 52.6 & & & 133.0 & & & & \\
\hline & $(40.9-105.1)$ & & & $(77.5-713.5)$ & & & & \\
\hline \multirow{2}{*}{ Cry2Ab } & 35.8 & & & 47.7 & & & \multirow{2}{*}{$10.3 \pm 1.4$} & \multirow{2}{*}{4.7} \\
\hline & $(30.7-40.9)$ & & & $(41.6-67.6)$ & & & & \\
\hline \multirow{2}{*}{ Cry2Aa-Cry2Ab } & 51.3 & \multirow{2}{*}{42.6} & 0.8 & 63.8 & \multirow{2}{*}{70.2} & \multirow{2}{*}{1.1} & \multirow{2}{*}{$13.5 \pm 2.0$} & \multirow{2}{*}{5.7} \\
\hline & $(47.1-56.1)$ & & & $(57.8-82.5)$ & & & & \\
\hline
\end{tabular}

a(CI Min. - Max.): confidence interval (95\%Cl); ${ }^{\text {b }} \pm$ (SE): slope and standard error; SF: synergism factor. 
Brazil, and reported mortality rates up to $70 \%$ for asbestos. B. thuringiensis subsp. israelensis bacterium is highly relevant in the fight against the vector of dengue viruses, because it acts as an efficient biolarvicide integrated in the scope of the PCA, conducted in several municipalities affected by the disease (BRAGA et al., 2004). The larvicide Bt-horus SC (B. thuringiensis subsp. israelensis - active principle) developed by Embrapa Genetic Researches and Biotechnology and Bthek Biotechnology was applied in São Sebastiáo (Distrito Federal, Brazil) successfully (MONNERAT et al., 2012). Furthermore, the research for new isolates and proteins with larvicidal toxicity against mosquito species vector of several diseases is a constant in biological control and aims to increase the efficacy of bioinsecticides (LOBO et al., 2018; SOARES-DA-SILVA et al., 2017; EL-KERSH, et al., 2016).

A previous study on the diversity of $B$. thuringiensis isolates conducted a search of the $c y t 1, c y t 2, c r y 2, c r y 4 A, c r y 4, c r y 10$, cry11, cry17, cry19, cry24, cry25, cry27, cry29, cry30, cry32, cry39 and cry 40 genes by polymerase chain reaction (PCR) and found four isolates (LBIT315, LBIT320, LBIT348, and IB604) more efficient than $B$. thuringiensis subsp. israelensis and one isolate (147-8906) slightly less toxic against $A$. aegypti larvae than $B$. thuringiensis subsp. israelensis positive control (IBARRA et al., 2010). However, the 147-8906 isolate, which carries the cry11,cyt1, cyt2 and cry30 genes, is highlighted, because it differs from $B$. thuringiensis subsp. israelensis control gene composition and maintains the insecticidal activity, despite having a lower number of genes. The use of toxins different from those present in the B. thuringiensis subsp. israelensis based on bioinsecticides can increase efficiency and prolong field use.

The search for gene-carrier isolates that are efficient to control dipterans such as $B$. thuringiensis thuringiensis strain T01-328 is important for controlling the vectors. The $c r y 4 A$, cry $4 B$, cyt 2 , cry 10 and cry 11 genes are commonly sought in B. thuringiensis isolates in order to control dipterans. EL-KERSH et al. (2014) searched for insecticidal genes in isolates from Saudi Arabia, including $c r y 2 A$ class genes, but $c r y 2$ class genes were not found. Some isolates analyzed by these authors were more efficient to control Aedes caspius and Culex pipiens than $B$. thuringiensis subsp. israelensis positive control. The tests with these isolates against $A$. caspius resulted in $\mathrm{LC}_{50}$ ranging from $0.6 \mu \mathrm{g} / \mathrm{mL}$ (the most efficient) to $83 \mu \mathrm{g} / \mathrm{mL}$ (the least efficient). Therefore, B. thuringiensis thuringiensis strain T01-328 efficiency is within the interval of these isolates and the Cry $2 \mathrm{Aa}+$ Cry $2 \mathrm{Ab}$ mixture had $\mathrm{LC}_{50}$ of $17 \mu \mathrm{g} / \mathrm{mL}$ against $A$. aegypti larvae (LIMA, 2009).

Previous studies have been performed with the Cry2Aa and Cry11A proteins of Bacillus thuringiensis subsp. kurstaki and $B$. thuringiensis subsp. israelensis, respectively, expressed by baculoviruses (LIMA, 2009). The results showed that Cry2Aa had no activity against $2^{\text {nd }}$ instar larvae of $A$. aegypti, whereas Cry11A had $\mathrm{LC}_{50}$ of $53.3 \mathrm{ng} / \mathrm{mL}$ and the $B$. thuringiensis israelensis standard subspecies had an even higher toxicity, $\mathrm{LC}_{50}$ of $2.2 \mathrm{ng} / \mathrm{mL}$. These results differ from those found in this work, because the Cry2Aa and Cry2Ab proteins of the T01-328 isolate were equally efficient to control $A$. aegypti larvae. These differences found between the two studies may stem from differences between mosquito populations, amino acid composition, and expression and preparation of toxins.

A study on the diversity of $c r y 2$ genes in $B$. thuringiensis isolates from China found 322 isolates that were $c r y 2$ gene carriers, while $c r y 2 A a$ and $c r y 2 A b$ were the most abundant (LIANG et al., 2011). In addition, toxicity studies against A. aegypti larvae showed that the Rpp39 isolate carrying the cry $2 A a$ gene was the least toxic $\left(\mathrm{LC}_{50}>100 \mu \mathrm{g} / \mathrm{mL}\right)$, whereas the Ywc5-4 $\left(\mathrm{LC}_{50} 23.42 \mu \mathrm{g} / \mathrm{mL}\right)$ isolates carrying the $c r y 2 A a$ gene, JF19-2 $\left(\mathrm{LC}_{50} 2.541 \mu \mathrm{g} / \mathrm{mL}\right)$ carrying $c r y 2 A g$, Bts carrying cry $2 A a / c r y 2 A b\left(\mathrm{LC}_{50} 17.65 \mu \mathrm{g} / \mathrm{mL}\right)$ were the most efficient to control $A$. aegypti.

The Cry2Aa protein also exhibits toxicity against Culex pipiens larvae, demonstrating synergistic interaction when mixed with Cry4B protein (ZGHAL et al., 2006). In addition to the high insecticidal potential of Cry $2 \mathrm{Aa}$ and Cry $2 \mathrm{Ab}$ proteins against $A$. aegypti larvae, this may be an indication that the $\mathrm{Cry} 2 \mathrm{Aa} / \mathrm{Cry} 2 \mathrm{Ab}$ mixture with other insecticidal toxins as Cry11 and Cry 4 may potentiate the control of this vector.

The ability of gene transfer in $B$. thuringiensis allows using recombinant proteins with better characteristics/traits to improve the activity, yield, and stability, expressing several genes of toxins of this bacterium, generating new active products. Thus, genetic modifications to build hybrid proteins obtained in Bt subspecies are possible from conjugation, transformation, and recombination (CÉRON, 2004).

Although $B$. thuringiensis subsp. israelensis is effective to control mosquitoes and it is a World Health Organization (WHO)-recommended larvicide for use in potable water to control $A$. aegypti larvae, replacing chemicals, the diversity found in isolates may benefit vector control. The search for new isolates and proteins with insecticidal activity is a constant in the field of biological control and aims at increasing the insecticidal activity of the products, generating alternatives for resistance management and reaching insects of agronomic importance or vectors of pathogens that are not susceptible to the existing resources. The study of the Cry2Aa and Cry2Ab proteins of the $B$. thuringiensis thuringiensis strain T01-328 is relevant, because it characterizes this strain and these toxins as promising for controlling $A$. aegypti, the vector of important diseases such as Zika, dengue, and Chikungunya.

\section{CONCLUSIONS}

The spore-crystal suspension of $B$. thuringiensis thuringiensis strain T01-328 is toxic to A. aegypti larvae; however, it 
showed lower insecticidal potential than the $B$. thuringiensis subsp. israelensis. Futhermore, Cry2Aa and Cry2Ab proteins have insecticidal activity against the vector $A$. aegypti and an additive mode of action. It is, therefore, recommended to search these genes in isolates that aim at controlling the A. aegypti larvae.

\section{ACKNOLEDGEMENTS}

To the São Paulo State Foundation for the Research Support (FAPESP) — Process \#2016/03108-5 — and to Dr. Wanderli Pedro Tadei researcher from Malaria and Dengue Laboratory of the National Research Institute of Amazonas (INPA), for the supply of eggs of $A$. aegypti.

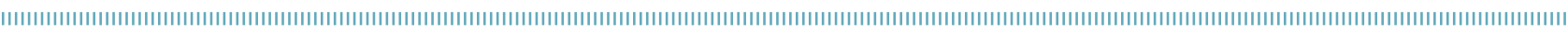
REFERENCES

ALVES, S.B.; MORAES, S.A. Quantificação de inóculo de patógenos de insetos. In: ALVES, S.B. Controle microbiano de insetos. 2 ed. Piracicaba: Fealq, 1998. p.765-777.

ARMENGOL, G.; ESCOBAR, M.C.; MALDONADO, M.E.; ORDUZ, S. Diversity of Colombian strains of Bacillus thuringiensis with insecticidal activity against dipteran and lepidopteran insects. Journal of Applied Microbiology, v.102, p.77-88, 2007.

BECKER, N. Bacterial control of vector-mosquitoes and black flies. In: CHARLES, J.F.; DELÉCLUSE, A.; LEROUX, C.N. (Ed.). Entomopathogenic bacteria: from laboratory to field application. Dordrecht: Kluwer Academic Publishers, 2000. p.383-398.

BEN-DOV, E. Bacillus thuringiensis subsp. israelensis and its dipteranspecific toxins. Toxins (Basel), v.6, n.4, p.1222-1243, 2014.

BRAGA, I.A.; LIMA, J.B.; SOARES, S.; VALLE, D. Aedes aegypti resistance to temephos during 2001 in several municipalities in the states of Rio de Janeiro, Sergipe and Alagoas, Brazil. Memórias do Instituto Oswaldo Cruz, v.99, p.199-203, 2004.

BRASIL. Boletim Epidemiológico. Secretaria de Vigilância em Saúde. Brasília, DF: Ministério da Saúde, 2018.

Portal Brasil. Ministério da Saúde atualiza situação do vírus Chikungunya. Brasília, DF: Ministério da Saúde, 2014. Available from: <http://www.brasil.gov.br/saude/2014/12/ministerioda-saude-atualiza-situacao-do-virus-chikungunya $>$. Accessed on: Jan. 112018.

. Fundação Nacional da Saúde (FUNASA). Monitoramento da resistência das populações de Aedes aegypti do país. Brasília, DF: Ministério da Saúde, 2000.

CÉRON, J. Productos comerciales: nativos y recombinants. In: BRAVO, A.; CÉRON, J. (Eds) Bacillus thuringiensis en el control biológico. Bogotá: Buena Semilla, 2004. p.127-147.

CRICKMORE, N.; ZEIGLER, D.R.; SCHENEPF, E.; VAN RIE, J.; LERECLUS, D.; BAUM, J.; BRAVO, A.; DEAN, D.H. Bacillus thuringiensis toxin nomenclature. Biols, 2016. Available from: <http://www.biols.susx.ac.uk/Home/Neil_crickmore/Bt/index. html>. Accessed on: Jan. 112018.

COSTA, J.R.V.; ROSSI, J.R.; MARUCCI, S.C.; ALVES, E.C.C.; VOLPE, H.X.L.; FERRAUDO, A.S.; LEMOS, M.V.F.; DESIDÉRIO, J.A. Atividade tóxica de isolados de Bacillus thuringiensis a larvas de Aedes aegypti (L) (Diptera: Culicidae). Neotropical Entomology, v.39, p.757-766, 2010.
D'ORTENZIO, E.; MATHERON, S.; YAZDANPANAH, Y.; DE LAMBALLERIE, X.; HUBERT, B.; PIORKOWSKI, G.; MAQUART, M.; DESCAMPS, D.; DAMOND, F.; LEPARC-GOFFART, I. Evidence of sexual transmission of Zika virus. The New England Journal of Medicine, v.374, n.22, p.2195-2198, 2016.

EL-KERSH, T.A.; AL-AKEEL, R.A.; AL-SHEIKH, Y.A.; ALHARBI, S.A. Isolation and distribution of mosquito-larvicidal cry genes in Bacillus thuringiensis strains native to Saudi Arabia. Tropical Biomedicine, v.31, n.4, p.616-32, 2014.

EL-KERSH, T.A.; AHMED, A.M.; AL-SHEIKH, Y.A.; TRIPET, F.; IBRAHIM, M.S.; METWALLI, A.A. Isolation and characterization of native Bacillus thuringiensis strains from Saudi Arabia with enhanced larvicidal toxicity against the mosquito vector Anopheles gambiae (s.l.). Parasites \& Vectors, v.9, n.1, p.647, 2016.

ESPINDOLA, C.B.; GUEDES, R.N.; SOUZA, R.C.P. Avaliação da eficácia do Bacillus thuringiensis var. israelensis no controle de formas imaturas do Aedes (Stegomyia) aegypti (Linnaeus, 1762) em ambiente de laboratório. EntomoBrasilis, v. 1, n. 1, p. 10-13, 2008.

FERNÁNDEZ-LUNA, M.T.; TABASHNIK, B.E.; LANZ-MENDOZA, H.; BRAVO, A.; SOBERÓN, M.; MIRANDA-RÍOS, J. Single concentration tests show synergism among Bacillus thuringiensis subsp. israelensis toxins against the malaria vector mosquito Anopheles albimanus. Journal of Invertebrate Pathology, v. 104, n.3, p.231-233, 2010.

GORDON, R.E.; HYDE, J.L. The Bacillus firmus-Bacillus lentus complex and $\mathrm{pH} 7.0$ variants of some alkalophilic strains. Microbiology, v.128, p.1109-1116, 1982.

IBARRA, J.E.; NOGUERA, P.A. Detection of new cry Genes of Bacillus thuringiensis by use of a novel PCR primer system. Applied and Environmental Microbiology, v.76, p.6150-6155, 2010.

INSECTICIDE RESISTANCE ACTION COMMITTEE (IRAC). Arthropod Pesticide Resistance Database (APRD). Michigan State University. Available from: <https://www.pesticideresistance.org/index. php>. Accessed on: Jan. 112018.

LAEMMLI, U.K. Cleavage of structural proteins during the assembly of the head of bacteriophage T4. Nature, v.227, p.680-685, 1970.

LEE, Y.W.; ZAIRI, J.; YAP, H.H.; ADANAN, C.R. Integration of Bacillus thuringiensis $\mathrm{H}-14$ formulations and Pyriproxyfen for the control of larvae of Aedes aegypti and Aedes albopictus. Journal of the American Mosquito Control Association, v.2 1, p.84-89, 2005. 
LIANG, H.; LIU, Y.; ZHU, J.; GUAN, P.; LI, S.; WANG, S.; ZHENG, A.; LIU, H.; LI, P. Characterization of cry2-type genes of Bacillus thuringiensis strains from soil isolated of sichuan basin, China. Brazilian Journal of Microbiology, v.42, p.140-146, 2011.

LIMA, G.M.S. Toxinas recombinantes Cry2Aa e Cry 11 Aa de Bacillus thuringiensis expressas em células de inseto são toxicas para larvas de Lepidoptera e Diptera. 105f. Thesis (Doutorado em Biologia Molecular) - Universidade de Brasília, Brasília, 2009.

LIMA, J.B.P.; MELO, N.V.; VALLE, D. Persistence of vectobac WDG and Metoprag S-2G against Aedes aegypti larvae using a semifield biossay in Rio de Janeiro. Revista do Instituto de Medicina Tropical de São Paulo, v.47, p.7-12, 2005.

LOBO, K.S.; SOARES-DA-SILVA, J.; SILVA, M.C.; TADEI, W.P.; POLANCZYK, R.A.; PINHEIRO, V.C.S. Isolation and molecular characterization of Bacillus thuringiensis found in soils of the Cerrado region of Brazil, and their toxicity to Aedes aegypti larvae. Revista Brasileira de Entomologia, v.62, p.5-12, 2018.

MANSUY, J.M.; PASQUIER, C.; DAUDIN, M.; CHAPUY-REGAUD, S.; MOINARD, N.; CHEVREAU, C.; IZOPET, J.; MENGELLE, C.; BUJAN, L. Zika virus in semen of a patient returning from a non-epidemic area. The Lancet. Infectious Diseases, v.16, n.8, p.894-895, 2016.

MONNERAT, R.; SOARES, C.M.; SANTOS, M.D.A.; OLIVEIRA, C.; CARDOSO, C.; LIMA, L.H.C.; PRAÇA, L.B.; MARTINS, E.S.; DUMAS, V.F.; QUEIROZ, P.R.M.; RAMOS, F.R.R.; SUJII, E. Controle de larvas de Aedes aegypti através da utilização de Bacillus thuringiensis em São Sebastião (DF), Brasil. Ciências da Saúde, v.10, n.2, p. $115-120,2012$.

REGIS, L.; SILVA-FILHA, M.H.; NIELSEN-LEROUX, C.; CHARLES, J.F. Bacteriological larvicides of dipteran disease vectors. Trends in Parasitology, v. 17, p.377-380, 2001.
SCHULER-FACCINI, L.; RIBEIRO, E.M.; FEITOSA, I.M.; HOROVITZ, D.G.; CAVALCANTI, D.P.; PESSOA, A.; DORIQUI, M.J.; NERI, J.I.; PINA NETO, J.M.; WANDERLEY, H.Y.C.; CERNACH, M.; EL-HUSNY, A.S.; PONE, M.S.; SERAO, C.L.; SANSEVERINO, M.T. Possible association between Zika virus infection and microcephaly - Brazil, 2015. Morbidity and Mortality Weekly Report, v.65, n.3, p.59-62, 2016.

SOARES-DA-SILVA, J.; QUEIRÓS, S.G.; AGUIAR, J.S.; VIANA, J.L.; NETA, M.D.R.A.V.; DA SILVA, M.C.; PINHEIRO, V.C.S.; POLANCZYK, R.A.; CARVALHO-ZILSE, G.A.; TADEI, W.P. Molecular characterization of the gene profile of Bacillus thuringiensis Berliner isolated from Brazilian ecosystems and showing pathogenic activity against mosquito larvae of medical importance. Acta Tropica, v.176, p.197-205, 2017.

TABASHNIK, B.E. Evaluation of synergism among Bacillus thuringiensis toxins. Applied Environmental Microbiology, v.58, p.3343-3346, 1992.

VARANI, A.M.; LEMOS, M.V.; FERNANDES, C.C.; LEMOS, E.G.; ALVES, E.C.; DESIDÉRIO, J.A. Draft genome sequence of Bacillus thuringiensis var. thuringiensis Strain T01-328, a Brazilian isolate that produces a soluble pesticide protein, Cry 1 la. Genome Announcements, v.1, p.5, 2013.

WORLD HEALTH ORGANIZATION - WHO. Guidelines for laboratory and field testing of mosquito larvicides. WHO/CDS/WHOPES/ GCDPP, 2005.

Dengue and severe dengue. 2017. Available from: <http:// www.who.int/mediacentre/factsheets/fs $117 /$ en/>. Accessed on: Jan. 112018.

ZGHAL, R.Z.; TOUNSI, S.; JAOUA, S. Characterization of a cry4Ba-type gene of Bacillus thuringiensis israelensis and evidence of the synergistic larvicidal activity of its encoded protein with $\mathrm{Cry} 2 \mathrm{~A} \delta$-endotoxin of $B$. thuringiensis kurstaki on Culex pipiens (common house mosquito). Applied Biochemistry and Biotechnology, v.44, p. 19-25, 2006. 